\title{
In vitro ruminal fermentation of fenugreek (Trigonella foenum- graecum L.) produced less methane than that of alfalfa (Medicago sativa)
}

\author{
Huaxin Niu ${ }^{1,2}$, Zhongjun $\mathrm{Xu}^{2}$, Hee Eun Yang ${ }^{2}$, Tim A McAllister ${ }^{2}$, Surya Acharya ${ }^{2}$, and Yuxi Wang ${ }^{2, *}$
}

\footnotetext{
* Corresponding Author: Yuxi Wang Tel: +1-403-317-3498, Fax: +1-403-382-3156

E-mail: yuxi.wang@canada.ca
}

${ }^{1}$ College of Animal Science and Technology, Inner Mongolia University for Nationalities, Tongliao, Inner Mongolia 028000, China

${ }^{2}$ Lethbridge Research and Development

Centre, Agriculture and Agri-Food Canada

(AAFC), Lethbridge, T1J4B1 Alberta, Canada

ORCID

Huaxin Niu

https://orcid.org/0000-0002-1047-6139

Zhongjun Xu

https://orcid org/0000-0002-1475-6736

Hee Eun Yang

https://orcid.org/0000-0001-7524-6484

Tim A McAllister

https://orcid.org/0000-0002-8266-6513

Surya Acharya

https://orcid.org/0000-0001-5965-3645

Yuxi Wang

https://orcid.org/0000-0002-6884-829X

Submitted Feb 21, 2020; Revised Mar 17, 2020; Accepted Apr 20, 2020
Objective: The objective of this study was to compare fenugreek (FG) with alfalfa (Alf) in ruminal fermentation and methane $\left(\mathrm{CH}_{4}\right)$ production in vitro.

Methods: Whole-plant FG harvested at 11- and 15-wk and Alf harvested at early and mid-bloom maturities, alone or as 50:50 mixture of FG and Alf at the respective maturity, were assessed in a series of 48 -h in vitro batch culture incubations. Total fermentation gas and methane gas production, dry matter (DM) disappearance, volatile fatty acids, microbial protein and 16S RNA gene copy numbers of total bacteria and methanogens were determined.

Results: Compared to early bloom Alf, FG harvested at 11-wk exhibited higher $(\mathrm{p}<0.05)$ in vitro DM and neutral detergent fibre disappearance, but this difference was not observed between the mid-bloom Alf and 15-wk FG. Regardless plant maturity, in vitro ruminal fermentation of FG produced less $(\mathrm{p}<0.001) \mathrm{CH}_{4}$ either on DM incubated or on DM disappeared basis than that of Alf during 48-h incubation. In vitro ruminal fermentation of FG yielded similar amount of total volatile fatty acids with higher $(\mathrm{p}<0.05)$ propionate percentage as compared to fermentation of Alf irrespective of plant maturity. Microbial protein synthesis was greater $(\mathrm{p}<0.001)$ with $11-w k$ FG than early bloom Alf as substrate and 16S RNA gene copies of total bacteria was higher ( $\mathrm{p}<0.01)$ with 15 -wk FG than mid-bloom Alf as substrate. Compared to mid-bloom Alf, 15 -wk FG had lower ( $p<0.05$ to 0.001 ) amount of $16 \mathrm{~S}$ RNA methanogen gene copies in the whole culture during 48-h incubation.

Conclusion: In comparison to Alf, FG emerges as a high quality forage that can not only improve rumen fermentation in vitro, but can also remarkably mitigate $\mathrm{CH}_{4}$ emissions likely due to being rich in saponins.

Keywords: Fenugreek; Alfalfa; In vitro; Methane; Rumen Bacteria

\section{INTRODUCTION}

Methane $\left(\mathrm{CH}_{4}\right)$ production by enteric fermentation in the rumen accounts for $2 \%$ to $12 \%$ of feed energy loss and is a green-house gas (GHG) that contributes to the global warming potential [1]. Decreasing ruminal $\mathrm{CH}_{4}$ production would not only reduce the release of this GHG into the atmosphere, but also possibly offer an avenue to improve feed efficiency in ruminants [2]. Therefore, it is urgently required that nutritionists explore anti-methanogenic substances, preferably through natural feed sources, for enhancing efficiency of nutrient utilization and eco-friendly ruminant production. Naturally occurring plant secondary compounds such as tannins and saponins have been shown to exhibit anti-methanogenic activity depending on source and concentrations [3-5]. Fenugreek (FG, Trigonella foenum-graecum L.) has been found to contain steroidal saponins that possess varying biological activities and FG seed and associated extracts have been exten- 
sively used as nutraceauticals in human healthcare [6-8].

Fenugreek is an annual legume that has great potential as a forage crop in Western Canada and in other parts of the world because of its sustained quality over the growing season and its drought and frost tolerance [6,9]. Fenugreek especially FG seed contains secondary metabolites including saponins, flavanoids, alkaloids and tannins $[7,8,10]$ that possess varying biological activities [11] and may impact nutrient digestion and metabolism and animal physiology when they are ingested. Researches have shown that FG forage is comparable to alfalfa (Alf) in terms of dry matter (DM) yield and nutrient content [12]. Several studies have been conducted to assess the nutritive value of whole plant FG as forage for cattle $[6,9,13]$. However, there is no information available on the effects of FG on ruminal $\mathrm{CH}_{4}$ production. The objective of this study was to compare the in vitro ruminal fermentation of FG and Alf with emphasis on its impact on $\mathrm{CH}_{4}$ production.

\section{MATERIALS AND METHODS}

\section{Substrate and inoculum}

Whole FG (Trigonella foenum-graecum; Tristar FG) plants at 11-and 15-wk after sowing and Alf (Medicago sativa; AC Grazeland $\mathrm{Br}$ ) at early bloom and mid bloom stages of the regrowth were cut above ground from three separate plots of the Swinton silt loam soil for each forage at the Lethbridge Research and Development Centre, AB, Canada. The seeding rate for FG was $15 \mathrm{~kg} / \mathrm{ha}$ and soil was amend to $45.4 \mathrm{~kg}$ available $\mathrm{N}$ at seeding. Edge pre-emergence herbicide was applied prior to seeding and Odyssey herbicide was applied during the growing season to control volunteer weeds. The Alf plots had been established for three years and have been used for hay production in previous years. The maturity of wholeplant FG harvested at 11 and $15 \mathrm{wk}$ after sowing corresponded to that of early- and mid-bloom Alf. Forage samples from the three plots were combined, freeze-dried and ground to pass through a $1-\mathrm{mm}$ screen.

In vitro incubations were conducted to compare the two forages at the two different maturities, with FG harvested at 11 wk comparing to Alf harvested at early bloom and a FG and Alf mixture at 50:50 ratio (DM basis; FA), and FG harvested at $15 \mathrm{wk}$ comparing to Alf harvested at mid-bloom and the corresponding 50:50 mixture (FA). Comparison between different maturities of the same forage was excluded because the focus of this study was to compare two forages.

The same three ruminally cannulated Angus heifers (550 \pm $50 \mathrm{~kg}$ body weight) were used as rumen fluid donors for all incubations. The heifers were fed (DM basis) a forage diet containing 50\% Alf hay, 35\% barley silage, $12 \%$ dry-rolled barley, and $3 \%$ of a vitamin and mineral supplement as per the National Research Council [14]. All heifers were fed at
08:00 $\mathrm{h}$ and provided ad libitum access to feed and water and were cared for in accordance with standards of Canadian Council on Animal Care [15]. Rumen fluid was collected 2 $\mathrm{h}$ after the morning feeding from five locations within the rumen, strained through four layers of cheesecloth, combined in equal volumes among three cattle and immediately transported in an anaerobic and pre-warmed container to the laboratory. Rumen fluid was then combined $(1: 2, \mathrm{v} / \mathrm{v})$ with pre-warmed $\left(39^{\circ} \mathrm{C}\right)$ mineral buffer [16] to generate the inoculum. The inoculum used for comparing FG harvested at $11 \mathrm{wk}$ to Alf harvested at early bloom was modified by replacing $1.0 \mathrm{~g} / \mathrm{L}$ of ammonium bicarbonate with equal amount of ${ }^{15} \mathrm{~N}$-enriched ammonium sulphate (Sigma Chemical Co, St Louis, MO, USA) to be used as microbial N marker.

\section{In vitro incubations and measurements}

Incubation was conducted in $125-\mathrm{mL}$ serum bottles with the preloaded $(0.5 \mathrm{~g})$ substrate of FG, Alf, or FA. Pre-warmed inoculum was dispensed under a stream of $\mathrm{O}_{2}$-free $\mathrm{CO}_{2}$ into pre-warmed serum vials $(60 \mathrm{~mL} / \mathrm{vial})$, immediately sealed and affixed to a rotary shaker platform $(140 \mathrm{rpm})$ in an incubator at $39^{\circ} \mathrm{C}$. Vials containing no substrate were also inoculated and incubated as blank controls. Vials for $0 \mathrm{~h}$ incubation were immediately placed into ice-water bath after inoculation. Incubation was repeated twice ( 2 runs) for the forages at early maturity and thrice for forages at later maturity (3 runs).

Gas production (GP) from each vial was measured after 6, 12,24 , and $48 \mathrm{~h}$ of incubation using a water displacement device as described by Wang et al [17]. A 15-mL gas sample was collected from each vial prior to gas measurement to determine $\mathrm{CH}_{4}$ concentration [18]. After gas measurement, three vials from each substrate and blank controls at each time point were placed on ice and processed to estimate DM disappearance (DMD), volatile fatty acid (VFA) and ammonia [3]. For the early maturing forages microbial $\mathrm{N}$ production was estimated using ${ }^{15} \mathrm{~N}$ as marker [3]. For mature forages, sub-samples $(2.0 \mathrm{~mL})$ of whole culture was collected from each vial for DNA extraction in order to estimate total bacteria and methanogens based on 16S rRNA and mcrA gene copies respectively.

DNA extraction and real-time quantitative polymerase chain reaction

Sample of whole cultures were lyophilized and ball ground using a planetary micro mill $(301 / \mathrm{S}, 3 \mathrm{~min}, 10-\mathrm{mm}$ steel balls, Retsch Inc., Newtown, PA, USA) and then metagenomic DNA was extracted using the Qiagen OIAamp DNA stool mini kit (Qiagen Inc., Valencia, CA, USA) as recommended by the manufacture with the exception that a beadbeating step ( 5 min, maximum speed) using a Bead Ruptor 24 Elite (Omni International Inc., Kennesaw, GA, USA) was 
added. Nucleic acids were precipitated with ammonium acetate and followed by isopropanol, washed twice with ethanol and suspended in Tris-ethylenediaminetetraacetic acid buffer. The quality of the DNA was assessed via electrophoresis on $1.2 \%$ agarose gel $(\mathrm{w} / \mathrm{v})$, and the DNA concentration of each sample was determined using a Nanodrop 2000 (Thermo Fisher Scientific Inc., Madison, WI, USA). The DNA samples were stored at $-40^{\circ} \mathrm{C}$ until analyzed.

The polymerase chain reaction (PCR) primers used for real-time quantitative PCR (qPCR) quantification of total bacteria and methanogens 16S rRNA and mcrA sequences are described in Table 1. Real-time qPCR amplification was performed on a Bio-Rad CFX 96 Connect Real-Time PCR Detection System (Bio-Rad Laboratories Inc., Hercules, CA, USA), and data were analyzed using Bio-Rad CFX Manager software (version 3.0). Standard curves were generated using 10-fold serial dilutions of DNA plasmid standards containing the target gene sequences of the respective microbial groups. Negative controls were included in the analyses $\left(\mathrm{H}_{2} \mathrm{O}\right.$ instead of DNA). The PCR cycling conditions were an initial denaturation step at $95^{\circ} \mathrm{C}$ for $3 \mathrm{~min}$, followed by 40 cycles of denaturation at $95^{\circ} \mathrm{C}$ for $25 \mathrm{~s}$, annealing at $50^{\circ} \mathrm{C}$ for $30 \mathrm{~s}$, and extension at $72^{\circ} \mathrm{C}$ for $45 \mathrm{~s}$. A melting curve analysis was performed by slowly cooling the reaction mixture from $95^{\circ} \mathrm{C}$ to $65^{\circ} \mathrm{C}$ to detect nonspecific amplification products. The copy number of marker genes of the total bacteria and methanogens were expressed per $\mathrm{ml}$ of whole culture.

\section{Chemical analysis}

The DM was determined by drying samples at $105^{\circ} \mathrm{C}$ for $16 \mathrm{~h}$ in a forced-air oven (AOAC, \# 930.15) [19] and organic matter was determined by ashing in a muffle furnace (AOAC, \# 943.01) [19]. The samples were ball ground in a planetary micro mill (Retsch Inc., USA) and analyzed for total N estimation by flash combustion analysis using a NA1500 nitrogen analyzer (Carlo Erba Instruments, MI, Italy). Neutral detergent fibre (NDF) and acid detergent fibre (ADF) were performed using an Ankom 200 system (Ankom Technology Corp., Fairport, NY, USA), with addition of sodium sulfite and alpha-amylase for NDF but without for ADF analysis as described by McGinn et al [20]. Content of steroidal saponins from FG and Alf was determined using method described by Wang et al [23] with smilagenin (Sigma,
USA) as a standard.

\section{Calculations and statistics analysis}

Microbial N production was calculated as described by Wang et al [3]. The in vitro NDF disappearance (NDFD) after 48-h incubation was calculated as the difference of NDF in the substrate before and after 48-h incubation. Calculations were calibrated by blank control.

The data were statistically analyzed using the Mixed procedure of SAS (SAS Institute Inc., Cary, NC, USA) as a randomized complete block design with treatment as the fixed effect, run as block and vials as statistical unit. The model used for analysis of time-course (repeated measures) data included time and the timextreatment interaction. Different variance and covariance assumption structures were initially test in the model and the type with lowest Akaike information criterion value was used in the final analysis. When these effects (time or timextreatment interaction) were significant (i.e. $\mathrm{p}<0.05$ ), means of the treatments were compared at each time point. Differences between treatment means was determined by LSMEANS with the PDIFF option in SAS and declared significant at $\mathrm{p}<0.05$.

\section{RESULTS}

Fenugreek harvested at $11 \mathrm{wk}$ had numerically higher concentration of crude protein (CP), but numerically lower concentrations of NDF and ADF than that harvested at 15 wk (Table 2). A similar trend was also observed for Alf harvested between early and mid-bloom stages. For substrates used in each comparison, FG had numerically lower concentrations of NDF and ADF but similar CP content as compared to Alf. The concentration of steroidal sapongenin in 11- and 15-wk FG were 113.2 and $95.8 \mathrm{mg}$ smilagenin equivalent/100 $\mathrm{g}$ DM respectively, but was not detectable in Alf.

Significant time effect $(\mathrm{p}<0.05)$ on fermentation products was observed and therefore data were presented at each time points. Fenugreek harvested at 11-wk had higher in vitro DMD at $6,12,24$, and 48 -h incubation ( $\mathrm{p}<0.05$ to 0.001 ) than Alf harvested at early bloom (Table 3 ). The FA also had higher in vitro DMD than Alf at 6 - and 48 -h incubation. In vitro NDFD at 48 - $h$ incubation was higher $(\mathrm{p}<0.05)$ for FG than for Alf and FA. On the contrary, GP (mL/g DM) from incu-

Table 1. Primers for real-time quantitative polymerase chain reaction

\begin{tabular}{lclccc}
\hline Target & Primer & Primer sequence (5'-3') & Amplicon size (bp) & $\begin{array}{c}\text { Annealing } \\
\text { temperature }\left({ }^{\circ} \mathbf{C}\right)\end{array}$ & Reference \\
\hline Total bacteria (16S) & F & CTCCTACGGGAGGCAGCAGT & 156 & 60 & {$[21]$} \\
& R & TTACCGCGGCTGCTGGCAC & & 58 & \\
Methanogens (mcrA) & F & TTCGGTGGATCDCARAGRGC & 140 & & \\
& R & GBARGTCGWAWCCGTAGAATCC & & \\
\hline
\end{tabular}


Table 2. Chemical composition ( $\mathrm{mg} / \mathrm{g}$ dry matter) of the forages

\begin{tabular}{|c|c|c|c|c|c|c|}
\hline Forages & Maturity & OM & $\mathrm{CP}$ & NDF & ADF & Steroidal saponin ${ }^{11}$ \\
\hline \multirow[t]{2}{*}{ Fenugreek } & $11 w k$ & $890.8 \pm 9.93$ & $235.5 \pm 1.67$ & $264.2 \pm 6.56$ & $229.3 \pm 2.16$ & $113.2 \pm 7.34$ \\
\hline & $15 w k$ & $890.0 \pm 2.18$ & $177.5 \pm 1.25$ & $377.9 \pm 5.31$ & $344.4 \pm 2.21$ & $95.8 \pm 3.24$ \\
\hline \multirow[t]{2}{*}{ Alfalfa } & Early bloom & $897.1 \pm 6.58$ & $211.6 \pm 1.72$ & $331.4 \pm 7.38$ & $279.9 \pm 3.69$ & ND \\
\hline & Mid bloom & $898.3 \pm 7.18$ & $173.7 \pm 2.51$ & $438.9 \pm 7.12$ & $371.1 \pm 4.13$ & ND \\
\hline
\end{tabular}

Mean \pm standard deviation, $n=4$.

$\mathrm{OM}$, organic matter; $\mathrm{CP}$, crude protein; NDF, neutral detergent fibre; ADF, acid detergent fibre; ND, not detected.

${ }^{1)} \mathrm{mg}$ smilagenin equivalent/100 $\mathrm{g}$.

Table 3. Dry matter disappearance (DMD), neutral detergent fibre disappearance (NDFD), gas production (GP) and methane production during 48-h in vitro ruminal incubation of forages in the early growth

\begin{tabular}{|c|c|c|c|c|c|c|}
\hline Item & Incubation time (h) & FG & FA & Alf & SEM & $\mathrm{p}$-value \\
\hline \multirow[t]{4}{*}{$\mathrm{DMD}(\%)$} & 6 & $35.4^{a}$ & $32.6^{a}$ & $29.2^{b}$ & 1.65 & 0.004 \\
\hline & 12 & $50.7^{\mathrm{a}}$ & $47.1^{\mathrm{ab}}$ & $43.1^{\mathrm{b}}$ & 2.01 & 0.048 \\
\hline & 24 & $60.2^{\mathrm{a}}$ & $55.7^{b}$ & $53.8^{\mathrm{b}}$ & 3.25 & 0.002 \\
\hline & 48 & $68.9^{\mathrm{a}}$ & $67.9^{\mathrm{a}}$ & $65.2^{b}$ & 0.71 & $<0.001$ \\
\hline NDFD (\%) & 48 & $44.3^{\mathrm{a}}$ & $40.7^{b}$ & $40.9^{b}$ & 0.81 & 0.016 \\
\hline \multirow[t]{4}{*}{$\mathrm{GP}(\mathrm{mL} / \mathrm{g} \mathrm{DM})$} & 6 & $95.5^{c}$ & $100.6^{b}$ & $103.5^{\mathrm{a}}$ & 8.79 & $<0.001$ \\
\hline & 12 & $165.8^{b}$ & $169.0^{b}$ & $172.4^{\mathrm{a}}$ & 3.57 & $<0.001$ \\
\hline & 24 & $190.9^{b}$ & $195.2^{\mathrm{ab}}$ & $197.5^{\mathrm{a}}$ & 2.74 & $<0.001$ \\
\hline & 48 & $202.3^{b}$ & $213.4^{\mathrm{a}}$ & $212.9^{\mathrm{a}}$ & 2.69 & 0.012 \\
\hline \multirow[t]{4}{*}{$\mathrm{CH}_{4}(\mathrm{~mL} / \mathrm{g} \mathrm{DM})$} & 6 & $12.0^{c}$ & $13.6^{\mathrm{b}}$ & $16.0^{\mathrm{a}}$ & 1.59 & $<0.001$ \\
\hline & 12 & $20.4^{c}$ & $22.4^{\mathrm{b}}$ & $26.5^{\mathrm{a}}$ & 4.27 & $<0.001$ \\
\hline & 24 & $25.4^{c}$ & $30.0^{b}$ & $34.3^{\mathrm{a}}$ & 3.08 & $<0.001$ \\
\hline & 48 & $32.8^{c}$ & $35.9^{b}$ & $38.3^{\mathrm{a}}$ & 2.91 & $<0.001$ \\
\hline \multirow[t]{4}{*}{$\mathrm{CH}_{4}(\mathrm{~mL} / \mathrm{g} \mathrm{DMD})$} & 6 & $34.2^{c}$ & $42.5^{b}$ & $55.3^{\mathrm{a}}$ & 6.63 & $<0.001$ \\
\hline & 12 & $41.4^{c}$ & $48.2^{b}$ & $62.1^{\mathrm{a}}$ & 12.27 & $<0.001$ \\
\hline & 24 & $42.8^{c}$ & $54.6^{b}$ & $64.1^{\mathrm{a}}$ & 8.67 & $<0.001$ \\
\hline & 48 & $47.7^{c}$ & $52.8^{b}$ & $58.8^{a}$ & 4.81 & $<0.001$ \\
\hline
\end{tabular}

DMD, Dry matter disappearance; NDFD, neutral detergent fibre disappearance; GP, gas production; $\mathrm{CH}_{4}$, methane FG, fenugreek; FA, mixture of fenugreek and alfalfa at the ratio of 50:50; Alf, alfalfa; SEM, standard error of the mean.

${ }^{a-c}$ Means within a row with different lowercased letters differ $(p<0.05)$.

bation of Alf was greater at $6,12,24$, and 48 -h incubation ( $\mathrm{p}<0.05$ to 0.001 ) than that of FG. $\mathrm{CH}_{4}$ production from 11 wk FG per g DM incubated was $15 \%$ to $33 \%$ lower $(\mathrm{p}<0.001)$ than for early bloom Alf after $6,12,24$, and $48 \mathrm{~h}$ of incubation. The difference of $\mathrm{CH}_{4}$ production between in vitro ruminal fermentation of FG and Alf at each incubation time point (23\% to $62 \%$ ) was even greater when $\mathrm{CH}_{4}$ production was expressed on per $\mathrm{g} \mathrm{DM}$ digested basis. $\mathrm{CH}_{4}$ production from in vitro ruminal fermentation of $\mathrm{FA}$ at each incubation time was intermediate and was higher $(\mathrm{p}<0.01)$ than that of FG, but lower $(p<0.01)$ than that of Alf either on the basis of DM incubated or DM digested.

With mature forages, no difference was found in in vitro DMD, 48-h NDFD and GP between FG harvested at 15 wk and Alf harvested at mid-bloom. In vitro DMD of FG at 24-h incubation was lower $(\mathrm{p}<0.05)$ than for Alf and FA (Table 4). In contrast, similar to that observed in FG harvested at $11 \mathrm{wk}$ and Alf harvested at early bloom, $\mathrm{CH}_{4}$ production from in vitro ruminal fermentation of FG at 6 to $48 \mathrm{~h}$ was lower ( $\mathrm{p}<$
0.01 to 0.001 ) than that from Alf with FA being intermediate. This difference was the same irrespective of expressing $\mathrm{CH}_{4}$ production on the basis of DM incubated or DM digested.

Fermentation of Alf harvested at early bloom stage yielded higher $(\mathrm{p}<0.01)$ ammonia concentration than 11-wk FG and FA at $6 \mathrm{~h}$ of incubation, but there was no difference in ammonia concentration among the three substrates between 12 and $48 \mathrm{~h}$ of incubation (Table 5). Similarly, there was no difference in total VFA concentration and molar percentage of acetate throughout the 48-h incubation. In contrast, molar percentage of propionate was higher ( $\mathrm{p}<0.05$ to 0.001 ), but molar percentage of butyrate was lower $(\mathrm{p}<0.01)$ for FG than Alf. Acetate:propionate ratio in VFA produced during 48-h fermentation of FG was lower ( $\mathrm{p}<0.05$ to 0.001 ) than Alf and the same difference was also observed between FA and Alf at 12, 24, and $48 \mathrm{~h}$ of the incubation.

With mature forages, ammonia concentration in the liquid fraction of the whole culture at 12 and 24-h incubation 
Table 4. Dry matter disappearance (DMD), neutral detergent fibre disappearance (NDFD), gas production (GP), and methane ( $\left.\mathrm{CH}_{4}\right)$ production during 48-h in vitro ruminal incubation of mature forages

\begin{tabular}{|c|c|c|c|c|c|c|}
\hline Item & Incubation time (h) & FG & FA & Alf & SEM & p-value \\
\hline \multirow[t]{4}{*}{$\operatorname{DMD}(\%)$} & 6 & 34.0 & 35.1 & 35.0 & 1.23 & 0.124 \\
\hline & 12 & 49.1 & 48.2 & 48.0 & 0.96 & 0.102 \\
\hline & 24 & $52.4^{b}$ & $55.5^{\mathrm{a}}$ & $54.8^{\mathrm{a}}$ & 2.00 & 0.013 \\
\hline & 48 & 67.4 & 67.9 & 66.3 & 0.64 & 0.086 \\
\hline NDFD (\%) & 48 & 40.5 & 41.4 & 40.3 & 0.96 & 0.668 \\
\hline \multirow[t]{4}{*}{$\mathrm{GP}(\mathrm{mL} / \mathrm{g} \mathrm{DM})$} & 6 & 93.8 & 95.6 & 94.1 & 1.69 & 0.105 \\
\hline & 12 & 139.6 & 141.9 & 139.3 & 1.47 & 0.294 \\
\hline & 24 & 177.6 & 180.0 & 176.7 & 1.95 & 0.305 \\
\hline & 48 & 196.3 & 203.7 & 201.1 & 4.12 & 0.438 \\
\hline \multirow[t]{4}{*}{$\mathrm{CH}_{4}(\mathrm{~mL} / \mathrm{g} \mathrm{DM})$} & 6 & $14.1^{c}$ & $16.1^{b}$ & $18.5^{\mathrm{a}}$ & 2.06 & $<0.001$ \\
\hline & 12 & $21.1^{c}$ & $25.3^{b}$ & $27.0^{\mathrm{a}}$ & 1.87 & $<0.001$ \\
\hline & 24 & $32.2^{b}$ & $38.2^{\mathrm{a}}$ & $38.7^{\mathrm{a}}$ & 2.88 & $<0.001$ \\
\hline & 48 & $42.2^{b}$ & $45.7^{\mathrm{a}}$ & $47.8^{\mathrm{a}}$ & 1.60 & 0.002 \\
\hline \multirow[t]{4}{*}{$\mathrm{CH}_{4}(\mathrm{~mL} / \mathrm{g} \mathrm{DMD})$} & 6 & $42.1^{b}$ & $46.9^{a}$ & $48.8^{a}$ & 4.51 & $<0.001$ \\
\hline & 12 & $47.1^{c}$ & $52.7^{b}$ & $56.3^{a}$ & 3.42 & $<0.001$ \\
\hline & 24 & $61.1^{b}$ & $68.9^{a}$ & $70.2^{a}$ & 3.71 & 0.017 \\
\hline & 48 & $62.7^{c}$ & $64.5^{\mathrm{b}}$ & $69.2^{\mathrm{a}}$ & 2.73 & $<0.001$ \\
\hline
\end{tabular}

$\mathrm{DMD}$, dry matter disappearance; NDFD, neutral detergent fibre disappearance; GP, gas production; $\mathrm{CH}_{4}$, methane; FG, fenugreek; FA, mixture of fenugreek and alfalfa at the ratio of 50:50; Alf, alfalfa; SEM, standard error of the mean.

${ }^{a-c}$ Means within a row with different lowercased letters differ $(p<0.05)$.

Table 5. Ammonia concentration and profile of volatile fatty acids (VFA) in liquid fraction of whole culture of in vitro ruminal incubation of forages in the early growth

\begin{tabular}{|c|c|c|c|c|c|c|}
\hline Item & Incubation time (h) & FG & FA & Alf & SEM & $\mathrm{p}$-value \\
\hline \multirow[t]{4}{*}{ Ammonia (mmol/L) } & 6 & $17.4^{\mathrm{a}}$ & $17.0^{\mathrm{a}}$ & $15.2^{b}$ & 0.36 & 0.004 \\
\hline & 12 & 20.7 & 20.8 & 19.5 & 1.88 & 0.166 \\
\hline & 24 & 27.3 & 28.0 & 26.3 & 0.68 & 0.189 \\
\hline & 48 & 34.6 & 35.4 & 34.1 & 1.58 & 0.110 \\
\hline \multirow[t]{4}{*}{ Total VFA (mmol/L) } & 6 & 60.4 & 56.6 & 60.4 & 2.44 & 0.239 \\
\hline & 12 & 73.5 & 68.7 & 71.2 & 2.83 & 0.474 \\
\hline & 24 & 82.6 & 85.1 & 87.9 & 2.67 & 0.346 \\
\hline & 48 & 83.8 & 94.7 & 94.4 & 3.76 & 0.095 \\
\hline \multirow[t]{4}{*}{ Acetate (\%) } & 6 & 68.0 & 67.4 & 67.8 & 0.52 & 0.358 \\
\hline & 12 & 67.2 & 66.5 & 66.9 & 0.58 & 0.176 \\
\hline & 24 & 65.8 & 65.3 & 65.8 & 0.74 & 0.086 \\
\hline & 48 & 64.7 & 65.1 & 65.9 & 0.55 & 0.114 \\
\hline \multirow[t]{4}{*}{ Propionate (\%) } & 6 & $19.9^{\mathrm{a}}$ & $18.9^{b}$ & $18.8^{b}$ & 0.19 & 0.001 \\
\hline & 12 & $19.0^{\mathrm{a}}$ & $18.5^{\mathrm{ab}}$ & $18.2^{b}$ & 0.10 & $<0.001$ \\
\hline & 24 & $19.0^{\mathrm{a}}$ & $18.4^{\mathrm{ab}}$ & $18.1^{b}$ & 0.26 & 0.013 \\
\hline & 48 & $18.5^{\mathrm{a}}$ & $18.1^{\mathrm{a}}$ & $17.5^{\mathrm{b}}$ & 0.18 & 0.007 \\
\hline \multirow[t]{4}{*}{ Butyrate (\%) } & 6 & $8.0^{b}$ & $9.0^{\mathrm{a}}$ & $9.0^{a}$ & 0.47 & 0.007 \\
\hline & 12 & $8.3^{b}$ & $9.4^{\mathrm{a}}$ & $9.8^{\mathrm{a}}$ & 0.41 & 0.002 \\
\hline & 24 & $8.9^{b}$ & $9.7^{\mathrm{a}}$ & $9.9^{a}$ & 0.27 & 0.003 \\
\hline & 48 & 9.3 & 9.6 & 9.8 & 0.36 & 0.711 \\
\hline \multirow[t]{4}{*}{ Branch chain VFA (\%) } & 6 & 2.9 & 2.9 & 2.9 & 0.20 & 0.932 \\
\hline & 12 & $4.7^{\mathrm{a}}$ & $4.5^{\mathrm{a}}$ & $4.0^{b}$ & 0.11 & 0.001 \\
\hline & 24 & 6.1 & 6.2 & 6.4 & 0.32 & 0.841 \\
\hline & 48 & 7.0 & 7.4 & 7.3 & 0.31 & 0.587 \\
\hline \multirow[t]{4}{*}{ Acetate:propionate } & 6 & $3.43^{b}$ & $3.56^{\mathrm{a}}$ & $3.60^{a}$ & 0.023 & 0.004 \\
\hline & 12 & $3.54^{b}$ & $3.59^{b}$ & $3.67^{a}$ & 0.031 & 0.011 \\
\hline & 24 & $3.47^{b}$ & $3.54^{\mathrm{b}}$ & $3.64^{a}$ & 0.096 & 0.018 \\
\hline & 48 & $3.50^{b}$ & $3.59^{b}$ & $3.76^{\mathrm{a}}$ & 0.067 & 0.046 \\
\hline
\end{tabular}

SEM, standard error of the mean.

VFA, volatile fatty acids; FG, fenugreek; FA, mixture of fenugreek and alfalfa at the ratio of 50:50; Alf, alfalfa; SEM, standard error of the mean.

a,b Means within a row with different lowercased letters differ $(p<0.05)$ 
was higher $(\mathrm{p}<0.01)$ for Alf than for FG (Table 6). However, this difference was not observed at 6 and $48 \mathrm{~h}$ of the incubation. Consistent with finding in FG harvested at $11 \mathrm{wk}$ and Alf harvested at early bloom, VFA concentrations were similar among three substrates regardless of the incubation time. Molar percentage of propionate ranked FG $>$ FA $>$ Alf $(p<0.001$ ), whereas molar percentages of butyrate and branch-chain VFA ranked Alf $>F A>F G(p<0.05$ to 0.001$)$ for all incubation times. There was no difference in total VFA concentration and molar percentage of acetate throughout the 48-h incubation. Acetate: propionate ratio in VFA produced during 48 - $\mathrm{h}$ fermentation was also ranked as Alf $>\mathrm{FA}>\mathrm{FG}(\mathrm{p}<0.001)$.

Microbial N production was greater $(\mathrm{p}<0.05)$ for $11-w \mathrm{k}$ FG than for early bloom Alf at 6, 12, 24, and 48-h incubation (Figure 1). There was no difference between FA and Alf in microbial $\mathrm{N}$ production at 24 and $48-\mathrm{h}$ incubation although incubation of FA produced more $(\mathrm{p}<0.05)$ microbial $\mathrm{N}$ than Alf at 6 and $12 \mathrm{~h}$ of the incubation.

$16 \mathrm{~S}$ rRNA copy numbers associated with total bacteria in the whole culture was greater at 12,24 , and $48 \mathrm{~h}$ of the incubation ( $\mathrm{p}<0.05$ to 0.01 ) for 15 -wk FG than for mid-bloom
Alf as substrate with FA being intermediate (Table 7). On the contrary, the amount of mcrA gene copies in the whole culture was greater $(\mathrm{p}<0.05$ to 0.001$)$ for Alf than for FG at 6 , 12 , and 24 - $h$ incubation and was slightly greater $(\mathrm{p}=0.093)$ for Alf than for FG at 48-h incubation.

\section{DISCUSSION}

There is little information on comparison of ruminal fermentation of FG and Alf forage. Mir et al [6] reported that 15- and 19-wk green-house grown FG had greater in vitro DMD than that of early bloom Alf but with similar VFA production. Mustafa et al [24] showed that 15-wk FG hay had higher ruminal degradabilities of $\mathrm{DM}, \mathrm{CP}$, and $\mathrm{ADF}$ and higher in vitro DMD compared to the full bloom regrowth Alf. The present study showed that GP for early bloom Alf was higher than those for 11-wk FG, which is consistent with the results of Mir et al [6], but no difference was found in GP from in vitro ruminal incubation of 15 -wk FG and mid-bloom Alf, which is in agreement with Farivar et al [25]. The discrepancy in GP among studies comparing FG and

Table 6. Ammonia concentration and profile of volatile fatty acids (VFA) in liquid fraction of whole culture of in vitro ruminal incubation of mature forages

\begin{tabular}{|c|c|c|c|c|c|c|}
\hline Item & Incubation time (h) & FG & FA & Alf & SEM & p-value \\
\hline \multirow[t]{4}{*}{ Ammonia (mmol/L) } & 6 & 11.6 & 11.9 & 12.1 & 0.52 & 0.458 \\
\hline & 12 & $14.4^{\mathrm{b}}$ & $16.6^{\mathrm{a}}$ & $17.2^{\mathrm{a}}$ & 0.39 & $<0.001$ \\
\hline & 24 & $22.6^{c}$ & $23.9^{b}$ & $25.2^{a}$ & 0.72 & 0.004 \\
\hline & 48 & 29.6 & 30.3 & 30.2 & 1.26 & 0.591 \\
\hline \multirow[t]{4}{*}{ Total VFA (mmol/L) } & 6 & 53.5 & 51.6 & 51.7 & 2.36 & 0.124 \\
\hline & 12 & 63.6 & 61.7 & 61.0 & 2.16 & 0.327 \\
\hline & 24 & 74.2 & 74.0 & 73.8 & 1.67 & 0.975 \\
\hline & 48 & 85.3 & 82.3 & 79.4 & 3.00 & 0.134 \\
\hline \multirow[t]{4}{*}{ Acetate (\%) } & 6 & $67.9^{b}$ & $68.1^{b}$ & $68.6^{a}$ & 0.28 & 0.002 \\
\hline & 12 & 66.7 & 66.8 & 67.1 & 0.23 & 0.186 \\
\hline & 24 & 65.2 & 65.3 & 65.7 & 0.14 & 0.060 \\
\hline & 48 & $64.8^{b}$ & $65.1^{\mathrm{ab}}$ & $65.4^{a}$ & 0.21 & 0.056 \\
\hline \multirow[t]{4}{*}{ Propionate (\%) } & 6 & $20.5^{a}$ & $19.6^{b}$ & $18.5^{\mathrm{c}}$ & 0.47 & $<0.001$ \\
\hline & 12 & $20.2^{a}$ & $19.5^{\mathrm{b}}$ & $18.5^{\mathrm{c}}$ & 0.57 & $<0.001$ \\
\hline & 24 & $20.1^{a}$ & $19.2^{b}$ & $18.5^{c}$ & 0.58 & $<0.001$ \\
\hline & 48 & $19.6^{a}$ & $18.7^{b}$ & $17.9^{c}$ & 0.53 & $<0.001$ \\
\hline \multirow[t]{4}{*}{ Butyrate (\%) } & 6 & $8.0^{\mathrm{b}}$ & $8.3^{\mathrm{ab}}$ & $8.7^{\mathrm{a}}$ & 0.59 & 0.008 \\
\hline & 12 & $8.7^{c}$ & $9.1^{b}$ & $9.5^{\mathrm{a}}$ & 0.62 & $<0.001$ \\
\hline & 24 & $9.3^{c}$ & $9.7^{\mathrm{b}}$ & $9.9^{\mathrm{a}}$ & 0.50 & $<0.001$ \\
\hline & 48 & $9.4^{c}$ & $9.7^{\mathrm{b}}$ & $9.8^{\mathrm{a}}$ & 0.51 & $<0.001$ \\
\hline \multirow[t]{4}{*}{ Branch-chain VFA (\%) } & 6 & $3.7^{b}$ & $3.9^{\mathrm{ab}}$ & $4.0^{\mathrm{a}}$ & 0.15 & 0.040 \\
\hline & 12 & $4.2^{c}$ & $4.5^{\mathrm{b}}$ & $4.8^{\mathrm{a}}$ & 0.16 & $<0.001$ \\
\hline & 24 & $5.2^{c}$ & $5.6^{b}$ & $5.8^{\mathrm{a}}$ & 0.11 & $<0.001$ \\
\hline & 48 & $6.0^{c}$ & $6.4^{\mathrm{b}}$ & $6.7^{\mathrm{a}}$ & 0.15 & $<0.001$ \\
\hline \multirow[t]{4}{*}{ Acetate:propionate } & 6 & $3.32^{c}$ & $3.48^{b}$ & $3.71^{\mathrm{a}}$ & 0.068 & $<0.001$ \\
\hline & 12 & $3.30^{c}$ & $3.43^{b}$ & $3.63^{a}$ & 0.087 & $<0.001$ \\
\hline & 24 & $3.25^{\mathrm{c}}$ & $3.40^{b}$ & $3.56^{a}$ & 0.097 & $<0.001$ \\
\hline & 48 & $3.32^{c}$ & $3.45^{b}$ & $3.65^{a}$ & 0.085 & $<0.001$ \\
\hline
\end{tabular}

VFA, volatile fatty acids; FG, fenugreek; Alf, alfalfa; FA, mixture of fenugreek and alfalfa at the ratio of 50:50; SEM, standard error of the mean.

${ }^{a-c}$ Means within a row with different lowercased letters differ $(p<0.05)$. 


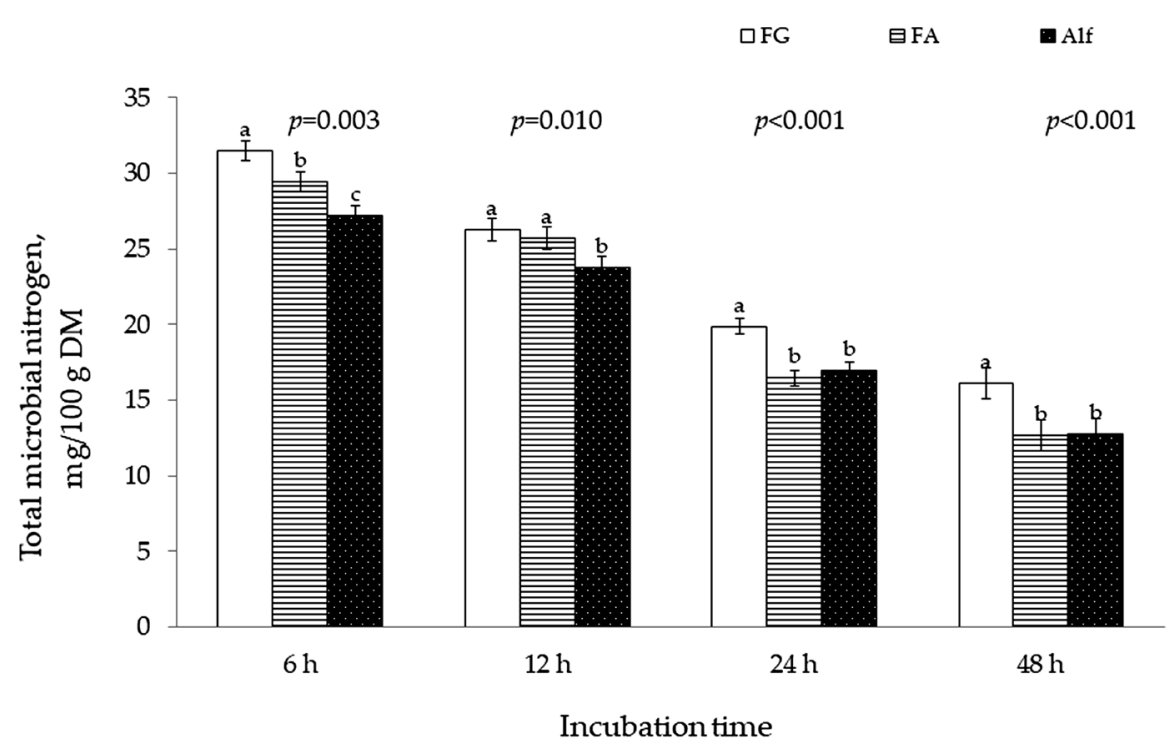

Figure 1. Microbial N production of fenugreek (FG) harvested at 11 wk, alfalfa (Alf) harvested at early bloom and their 50:50 mixture (FA) during 48-h in vitro ruminal incubation.

Alf could be attributed to different maturities of the forages used in these studies. Nevertheless, the observations of greater in vitro DMD but less GP with 11-wk FG than with early bloom Alf indicated that in vitro ruminal fermentation of 11-wk FG was more efficient towards to producing microbial protein than that of early bloom Alf because total VFA production was similar between the two forages. This is supported by the observations that microbial protein synthesis was greater for in vitro fermentation of 11-wk FG than for early bloom Alf and that total bacteria populations was higher for in vitro fermentation of 15 -wk FG than for mid-bloom Alf in this study.

Incubation of FG led to greater microbial N in FG harvested at $11 \mathrm{wk}$ than Alf harvested at early bloom was consistent with greater total bacterial population in FG harvested at $15 \mathrm{wk}$ and Alf harvested at mid-bloom. This suggests, regardless of the plant maturity, that fermentation of FG would yield greater microbial protein than fermenta- tion of Alf. This is likely due to the numerically lower NDF and ADF but slightly higher N in FG than in Alf, as well as the presence of plant secondary compounds such as steroidal saponin in FG. Antimicrobial and anti-protozoal activity of steroidal saponin are well recognized, which are bacterial species specific, mainly inhibiting $\mathrm{G}^{+}$positive bacteria. However, Wang et al [3] showed dose-dependent response of rumen microbial protein synthesis to steroidal saponin from Yucca schidigera (Y. schidigera), with the concentration of $15 \mu \mathrm{g} / \mathrm{mL}$ increasing microbial protein synthesis and higher than that decreasing microbial production. Estimated steroidal saponin (from FG) concentration in the whole culture of this study ranged 10 to $12 \mu \mathrm{g} / \mathrm{mL}$. At these concentrations, FG steroidal saponin may also have promoted microbial protein synthesis. Dey et al [26] also showed saponin extracts from FG leaves increased microbial protein synthesis.

The most interesting finding of the study was that ruminal fermentation of FG produced less $\mathrm{CH}_{4}$ than fermentation of

Table 7. 16S rRNA gene copy numbers of total bacteria and methanogen archaea in the whole culture of in vitro ruminal incubation of mature forages

\begin{tabular}{|c|c|c|c|c|c|c|}
\hline Item & Incubation time (h) & FG & FA & Alf & SEM & p-value \\
\hline \multirow[t]{4}{*}{ Total bacteria $\left(\times 10^{8} / \mathrm{mL}\right)$} & 6 & 9.62 & 8.64 & 7.81 & 1.696 & 0.185 \\
\hline & 12 & $9.84^{\mathrm{a}}$ & $7.72^{b}$ & $6.47^{b}$ & 0.960 & 0.007 \\
\hline & 24 & $6.61^{a}$ & $4.86^{b}$ & $4.68^{b}$ & 0.552 & 0.042 \\
\hline & 48 & $2.50^{\mathrm{a}}$ & $2.68^{a}$ & $1.77^{\mathrm{b}}$ & 0.282 & 0.023 \\
\hline \multirow[t]{4}{*}{ Methanogen $\left(\times 10^{4} / \mathrm{mL}\right)$} & 6 & $1.44^{b}$ & $1.84^{\mathrm{ab}}$ & $1.90^{\mathrm{a}}$ & 0.795 & 0.042 \\
\hline & 12 & $1.94^{b}$ & $1.61^{\mathrm{ab}}$ & $2.25^{\mathrm{a}}$ & 0.784 & 0.036 \\
\hline & 24 & $2.10^{\mathrm{C}}$ & $3.02^{b}$ & $4.23^{\mathrm{a}}$ & 0.533 & $<0.001$ \\
\hline & 48 & 2.26 & 2.63 & 2.94 & 0.452 & 0.093 \\
\hline
\end{tabular}

FG, fenugreek; Alf, alfalfa; FA, mixture of fenugreek and alfalfa at the ratio of 50:50; SEM, standard error of the mean.

$a, b$ Means within a row with different lowercased letters differ $(p<0.05)$. 
Alf and this was consistent across two maturities of the two forages and expressed either on per unit of DM incubated or on the basis of DM disappeared. It is commonly accepted that feedstuffs which have higher GP and in vitro DMD tend to have higher $\mathrm{CH}_{4}$ production per gram DM incubated [4, $26,27]$. The observation of less methane production of FG than that of Alf despite the discrepancies in DMD and GP per unit of substrate between the two forages at two maturities indicated FG may contain specific anti-methanogenic activity. This is supported by the observation of lower methanogen gene copies with FG than with Alf. Several biological compounds such as steroidal saponins and phenolic compounds that possess varying biological activities have been found in FG $[11,12,28]$. Among them, steroidal saponins have been reported to possess anti-methanogenic activity in both in vitro or in vivo studies $[4,29,30]$. In this study, steroidal saponin was found in FG but not in Alf. Other studies also reported that FG and its seed extracts are rich in saponins $[6,8,12]$. Therefore, compared to Alf it is likely that steroidal saponins in FG contributed to its lower methane production during ruminal fermentation. It needs to be pointed out that this study used whole-plant FG and Alf as substrates and therefore was unable to identified exactly what factor or factors in FG lead to the decreased methane production compared to Alf. Further research is needed to elucidate the mechanism by which ruminal fermentation of FG yielded lower methane production than that fermentation of Alf.

The lower methane production was accompanied by higher propionate and lower acetate: propionate ratio in VFA for in vitro ruminal fermentation of FG than that of Alf in this study. Propionate is generally regarded as an alternative metabolic $\mathrm{H}_{2}$ sink to methane during rumen fermentation. This suggests that either fermentation of FG enhanced propionate production thereby decreased $\mathrm{H}_{2}$ sink to methane formation, or decreased methane production through decreasing methanogenic activity and thereby increased $\mathrm{H}_{2}$ as a sink to propionate. Studies have shown that plants rich in saponins selectively modulated the rumen microbial populations resulting in an improvement of rumen fermentation towards enhanced propionate and decreased $\mathrm{CH}_{4}$ production $[31,32]$. Our previous studies demonstrated that steroidal saponin from $Y$. schidigera selectively decreased ruminal cellulolytic bacteria activity but increased Selenomonas ruminantium, a propionate-producing bacteria, resulting in decreased acetate: propionate ratio [33]. Meta-analyses also showed that saponins or saponin containing plants increased propionate concentrations [7] and that decreased $\mathrm{CH}_{4}$ production was accompanied by reduced acetate:propionate [32]. In addition, rumen enteric microbiome were modified when plants rich in saponins were fed to ruminant livestock, resulting in increased propionate, and decreased methane production
$[33,34]$. Therefore, it is likely that the presence of steroidal saponin in FG but not in Alf in this study contributed to the increased propionate production during ruminal fermentation of FG.

Jayanegara et al [4] summarized in vitro studies on effects of saponins from Y. schidigera, Quillaja and tea on ruminal fermentation and found that steroidal saponins from all of these sources decreased methane production and acetate: propionate ratio with no or little effects on total GP or DMD. These results as well as the work of others [29] suggest that steroidal saponin from FG may have similar effects on ruminal fermentation to other reported steroidal saponin. Further research is needed to define the role of FG saponins in modifying ruminal fermentation in particular its effects on rumen microbial activity, VFA profile and methane production.

The difference of ammonia concentration in fermentation liquid fraction between two forages is likely attributable to the differences in $\mathrm{N}$ and plant secondary contents. It has been shown that ammonia accumulation in closed in vitro system increased as the substrate $\mathrm{N}$ increasing [35]. Both FG and Alf contained numerically higher $\mathrm{N}$ at early than late maturity. At early maturity, FG also contained numerically higher $\mathrm{N}$ than Alf. These may partially explain the higher ammonia concentration resulted from fermentation of early mature than late mature FG and Alf and from 11-wk FG than early bloom Alf. However, the inconsistent difference in ammonia concentration between FG and Alf in different mature stages may indicate effects of plant secondary compounds in FG on $\mathrm{N}$ metabolism in the rumen was not as obvious as that observed on methane production. A common observation of plant polyphenolic compounds effects on rumen fermentation is the decrease of ammonia concentration [36]. Previous researches have showed that $Y$. schidigera, steroidal saponins decreased ruminal ammonia concentration [3], but this was not observed for Quillaja and tea saponins [4]. Nevertheless, the lower ammonia concentration was accompanied with lower branch-chain VFA concentration for fermentation of 15-wk FG than for that of mid bloom Alf. This coupling with the similar $\mathrm{N}$ content of the two forages at mature stage indicated that protein degradation might have been decreased by FG plant secondary compounds in this study.

\section{CONCLUSION}

Fenugreek harvested at $11 \mathrm{wk}$ had higher in vitro ruminal fermentation than early bloom Alf. However, regardless of plant maturity, in vitro ruminal fermentation of FG produced less methane than fermentation of Alf either on DM incubated or on DM digested basis, partially due to the presence of steroidal saponins in FG. Fermentation of FG also produced VFA with higher propionate proportion and lower acetate:propionate ratio and yielded greater amount of micro- 
bial protein or larger bacterial population than Alf. Therefore, whole plant FG could be an alternative legume forage for ruminants, in particular in mitigation of enteric methane emission from the cattle industry. Animal studies need to be conducted to confirm its in vivo effects.

\section{CONFLICT OF INTEREST}

We certify that there is no conflict of interest with any financial organization regarding the material discussed in the manuscript.

\section{ACKNOWLEDGMENTS}

This research was supported by a grant from National Natural Science Foundation of Inner Mongolia Autonomous Region (No.2018MS03022), First Level Training Project of Inner Mongolia Autonomous Region "Prairie Talent Project" Youth Innovation and Entrepreneur Talents and AAFC. N.H.X. acknowledges the China Scholarship Council for awarding scholarship to conduct this research at Lethbridge Research and Development Centre of AAFC.

\section{REFERENCES}

1. Grossi G, Goglio P, Vitali A, Williams AG. Livestock and climate change: impact of livestock on climate and mitigation strategies. Anim Front 2019;9:69-76. https://doi.org/10.1093/ af/vfy034

2. Connor EE. Invited review: improving feed efficiency in dairy production: challenges and possibilities. Animal 2015;9:395408. https://doi.org/10.1017/S1751731114002997

3. Wang Y, McAllister TA, Yanke LJ, Xu ZJ, Cheeke PR, Cheng $\mathrm{KJ}$. In vitro effects of steroidal saponins from Yucca schidigera extract on rumen microbial protein synthesis and ruminal fermentation. J Sci Food Agric 2000;80:2114-22. https://doi. org/10.1002/1097-0010(200011)80:14<2114::AID-JSFA755 $>3.0 . \mathrm{CO} ; 2-0$

4. Jayanegara A, Wina E, Takahashi J. Meta-analysis on methane mitigating properties of saponin-rich sources in the rumen: influence of addition levels and plant sources. Asian-Australas J Anim Sci 2014;27:1426-35. https://doi.org/10.5713/ajas. 2014.14086

5. Lakhani N, Lakhani P. Plant secondary metabolites as a potential source to inhibit methane production and improve animal performance. Int J Chem Stud 2018;6:3375-9.

6. Mir Z, Acharya SN, Mir PS, et al. Nutrient composition, in vitro gas production and digestibility of fenugreek (Trigonella foenum-graecum) and alfalfa forages. Can J Anim Sci 1997; 77:119-24. https://doi.org/10.4141/A96-061

7. Murlidhar M, Goswami TK. A review on the functional properties, nutritional content, medicinal utilization and potential application of fenugreek. J Food Process Technol 2012;3:181.

8. Pant NC, Dhoundiyal R, Kumar M, Dwivedi U, Singh JP, Agrawal S. Fenugreek (Trigonella foenum-graecum L.) A potential source of dietary fibres and steroidal sapogenin (diosgenin). Int J Chem Stud 2018;6:612-8.

9. Doepel L, Montgomery JE, Beauchemin KA, King JR, Acharya SN. Ruminal degradability and whole-tract digestibility of protein and fibre fractions in fenugreek haylage. Can J Anim Sci 2012;92:211-7. https://doi.org/10.4141/cjas2011-101

10. Abdouli H, Ayed MH, Elham M, Nabila B, Morencos MRA. Proximate composition, and total phenols, tannins, flavonoids and saponins, and in vitro ruminal fermentation activity of fenugreek cut at three maturity stages. Livest Res Rural Dev 2012;24:13.

11. Yadav UCS, Baquer NZ. Pharmacological effects of Trigonella foenum-graecum L. in health and disease. Pharm Biol 2014; 52:243-54. https://doi.org/10.3109/13880209.2013.826247

12. Acharya SN, Thomas JE, Basu SK. Fenugreek, an alternative crop for semiarid regions of North America. Crop Sci 2008; 48:841-53. https://doi.org/10.2135/cropsci2007.09.0519

13. Alemu AW, Doepel L. Fenugreek (Trigonella foenum-graecum L.) as an alternative forage for dairy cows. Animal 2011;5: 1370-81. https://doi.org/10.1017/S1751731111000322

14. Committee on Nutrient Requirements of Small Ruminants, NRC. Nutrient requirements of small ruminants: sheep, goats, cervids, and new world camelids. 7 th ed. Washington, DC, USA: National Academies Press; 2007. https://doi.org/ 10.17226/11654

15. Canadian Council on Animal Care (CCAC). CCAC guidelines on the care and use of farm animals in research, teaching and testing. Ottawa, ON, Canada: CCAC; 2009.

16. Menke KH, Raab L, Salewski A, Steingass H, Fritz D, Schneider $\mathrm{W}$. The estimation of the digestibility and metabolizable energy content of ruminant feedingstuffs from the gas production when they are incubated with rumen liquor in vitro. J Agric Sci 1979;93:217-22. https://doi.org/10.1017/S002185 9600086305

17. Wang Y, Ramirez-Bribiesca JE, Yanke LJ, Tsang A, McAllister TA. Effect of exogenous fibrolytic enzyme application on the microbial attachment and digestion of barley straw in vitro. Asian-Australas J Anim Sci 2012;25:66-74. https://doi. org/10.5713/ajas.2011.11158

18. Wang Y, Xu Z, Bach SJ, McAllister TA. Effects of phlorotannins from Ascophyllum nodosum (brown seaweed) on in vitro ruminal digestion of mixed forage or barley grain. Anim Feed Sci Technol 2008;145:375-95. https://doi.org/10.1016/ j.anifeedsci.2007.03.013

19.AOAC. Official methods of analysis of the association of official agricultural chemists. 16th ed, 5th rev. Gaithersburg, MD, USA: AOAC International; 1999.

20.McGinn SM, Beauchemin KA, Coates T, Colombatto D. 
Methane emissions from beef cattle: effects of monensin, sunflower oil, enzymes, yeast, and fumaric acid. J Anim Sci 2004;82:3346-56. https://doi.org/10.2527/2004.82113346x

21. Oss DB, Ribeiro GO, Marcondes MI, et al. Synergism of cattle and bison inoculum on ruminal fermentation and select bacterial communities in an artificial rumen (Rusitec) fed a barley straw based diet. Front Microbiol 2016;7:2032. https://doi. org/10.3389/fmicb.2016.02032

22.Denman SE, Tomkins NW, McSweeney CS. Quantitation and diversity analysis of ruminal methanogenic populations in response to the antimethanogenic compound bromochloromethane. FEMS Microbiol Ecol 2007;62:313-22. https:// doi.org/10.1111/j.1574-6941.2007.00394.x

23.Wang Y, McAllister TA. A modified spectrophotometric assay to estimate deglycosylation of steroidal saponin to sapogenin by mixed ruminal microbes. J Sci Food Agric 2010;90:1811-8. https://doi.org/10.1002/jsfa.4019

24. Mustafa AF, Christensen DA, McKinnon JJ. In vitro and in situ evaluation of fenugreek (Trigonella foenum-graecum) hay and straw. Can J Anim Sci 1996;76:625-8. https://doi. org/10.4141/cjas96-092

25. Farivar F, Torbatinejad NM, Jafari Ahangari Y, Hasani S, Gharebash AM, Mohajer M. In vitro evaluation of alfalfa substitution with fenugreek (Trigonella foenum graegum) hay in a high concentrate ration. Iran J Appl Anim Sci 2014; 4:291-6.

26. Dey A, Paul SS, Pandey P, et al. Effect of fenugreek leaf extract (Trigonella foenum-graecum L.) on in vitro methanogenesis and fermentation of wheat straw-based diet (Triticum aestivum L.) fed to buffaloes. Sri Lanka J Food Agric 2015;1:9-13.

27.Durmic Z, Hutton P, Revell DK, Emms J, Hughes S, Vercoe PE. In vitro fermentative traits of Australian woody perennial plant species that may be considered as potential sources of feed for grazing ruminants. Anim Feed Sci Technol 2010;160: 98-109. https://doi.org/10.1016/j.anifeedsci.2010.07.006

28. Chaudhary S, Chaudhary PS, Chikara SK, Sharma MC, Iriti M. Review on fenugreek (Trigonella foenum-graecum L.) and its important secondary metabolite diosgenin. Not Bot
Horti Agrobot Cluj Napoca 2018;46:22-31. https://doi.org/ 10.15835/nbha46110996

29. Goel G, Makkar HPS. Methane mitigation from ruminants using tannins and saponins. Trop Anim Health Prod 2012; 44:729-39. https://doi.org/10.1007/s11250-011-9966-2

30.Jafari S, Ebrahimi M, Goh YM, Rajion MA, Jahromi MF, AlJumaili WS. Manipulation of rumen fermentation and methane gas production by plant secondary metabolites (saponin, tannin and essential oil) - a review of ten-year studies. Ann Anim Sci 2019;19:3-29. https://doi.org/10.2478/ aoas-2018-0037

31. Kamra DN, Agarwal N, Chaudhary LC. Inhibition of ruminal methanogenesis by tropical plants containing secondary compounds. Int Congr Ser 2006;1293:156-63. https://doi. org/10.1016/j.ics.2006.02.002

32.Ugbogu EA, Elghandour MMMY, Ikpeazu VO, et al. The potential impacts of dietary plant natural products on the sustainable mitigation of methane emission from livestock farming. J Clean Prod 2019;213:915-25. https://doi.org/10. 1016/j.jclepro.2018.12.233

33. Wang Y, McAllister TA, Yanke LJ, Cheeke PR. Effect of steroidal saponin from Yucca schidigera extract on ruminal microbes. J Appl Microbiol 2000;88:887-96. https://doi.org/10.1046/j. 1365-2672.2000.01054.x

34. Tapio I, Snelling TJ, Strozzi F, Wallace RJ. The ruminal microbiome associated with methane emissions from ruminant livestock. J Anim Sci Biotechnol 2017;8:7. https://doi.org/ 10.1186/s40104-017-0141-0

35.Peng K, Gresham GL, McAllister TA, et al. Effects of inclusion of purple prairie clover (Dalea purpurea Vent.) with native cool-season grasses on in vitro fermentation and in situ digestibility of mixed forages. J Anim Sci Biotechnol 2020;11:23. https://doi.org/10.1186/s40104-019-0418-6

36. Waghorn G. Beneficial and detrimental effects of dietary condensed tannins for sustainable sheep and goat production - progress and challenges. Anim Feed Sci Technol 2008; 147:116-39. https://doi.org/10.1016/j.anifeedsci.2007.09.013 